\title{
Reunion of International Couples in Formal and Informal Relationships during the COVID-19 Pandemic.
}

\author{
Youngcho Lee $^{\mathrm{a}} ;$ Pilar Wiegand $^{\mathrm{a}} ;$ Laura Odasso $^{\mathrm{b}} ;$ Jacques Wels $^{\mathrm{c}^{*}}$ \\ ${ }^{a}$ University of Cambridge, Department of Sociology \\ ${ }^{\mathrm{b}}$ Collège de France \& French Collaborative Institute on Migrations, Paris \\ ${ }^{c}$ University College London, Faculty of Population Health Sciences, Centre for Longitudinal Studies \\ (CLS) \\ "Corresponding author: jcqwels@gmail.com
}

Version: $11^{\text {th }}$ of October 2021 


\begin{abstract}
The COVID-19 epidemic has generated major social disruptions, including the implementation of border enforcement measures in many countries to contain international travel. As tourism has been the most frequent means for international couples to reunite, a minority of countries have implemented specific measures to allow foreign partners to cross the borders. The purpose of this article is to provide a global overview of the regulations of cross-border travel for couples respectively in formal and informal relationships. This research is based on data on travel guidelines from 175 countries and a typology that distinguishes countries that have not implemented travel restrictions (46\%), countries that have enacted border enforcement regulations but with special measures to allow formal and informal couples (15\%), countries with border enforcement and special measures for formal couples only (15\%) and countries that have implemented a travel ban with no special measures (23\%). Results show that the specific measures for formal and informal couples are implemented independently from the region but with much higher propensities in high-income countries. However, the administrative requirements, particularly for informal couples, vary greatly among the countries that allow couples to reunite. The article concludes that exemptions are key when analysing border closures and that specific measures could be applied more inclusively to allow informal couples to reunite.
\end{abstract}

Keywords: Family Reunion, Border Control, \#LoveIsNotTourism, COVID-19, Migration, Informal Couples 


\section{Key findings:}

- Most countries have implemented some kind of border enforcement measures and temporarily suspended tourism.

- A limited number of countries have implemented specific exemptions to allow couples in formal relationships to reunite.

- An even smaller number of countries — most of them high income - have implemented exemptions for couples in informal relationships.

- Among countries that have implemented specific exemptions for couples in informal relationships to reunite, there exists great variability in the documentation that needs to be submitted to prove the relationship as well as the purpose and timespan for reunion.

- The cross-national heterogeneities concerning administrative requirements reflect the country's recognition of informal unions as an alternative to formalised relationships, especially marriage.

- Rather than reverting the restrictions applied to international couples to reunite via tourist routes after the end of the pandemic, we suggest that specific border regulations may be investigated to facilitate the mobility of international couples, especially those in informal relationships. 


\section{Background}

The COVID-19 pandemic and the many measures implemented to contain its spread have led to major social disruptions, including lockdowns, closures of various facilities, implementation of social distancing measures, and quarantines for travellers. These disruptions have affected all aspects of social lives, and in many ways, have revealed and/or amplified pre-existing inequalities (Marmot \& Allen, 2020). Among the diverse restrictions and measures that were implemented and are still in place in most countries at the time this article was written - border enforcement measures have played a significant role in limiting international mobility (Haug et al., 2020). As most countries have implemented strict(er) border enforcement measures to reduce cross-border travel, tourist visas or visa waiver programmes have been suspended and travel permits based on the grounds of education, employment and family reunion have also been limited in many countries. Such a sharp increase in border control has particularly curtailed the mobility of international couples in legally recognised relationships such as marriages and civil unions and to an even greater extent, those in romantic but informal relationships. Such international couples have been unable to reunite as they would have done prior to the pandemic via, for instance, the tourist visa routes.

Social media campaigns, most notably via the \#LoveIsNotTourism movement, have raised awareness about the effects of border enforcement measures on informal couples and advocated policy changes over the past two years. In contrast, little systematic academic research has been conducted on the COVID-19 travel restrictions for international couples, both in formal (herein referring to marriage or civil partnership) or informal (co-residential or other romantic) relationships. This study seeks to examine the different travel regulations implemented worldwide, how these have affected the international mobility of those in formal and informal relationships and how policies could better facilitate cross-border migration for international couples. The purpose of this study is not to focus on individuals' couples' experiences of border enforcement from a micro perspective - as it has been done in pre-pandemic (Odasso, 2021a; 2021b) or in pandemic (Odasso \& Fogel, 2022) settings -, but rather to outline the ways different countries have been regulating 'love migration' from a macro, cross-national point of view.

The article is organised as follows. First, we briefly explain how the COVID-19 context has affected international mobility on the one hand and discuss the challenges international couples have faced even prior to the start of the pandemic on the other hand. The second section overviews the data collection and analysis strategies. The third section presents the main descriptive findings based on a typology of four different levels of border enforcement measures for couples in formal and informal relationships. The fourth section illustrates the diversity of the measures around the world via thematic comparative case studies. Finally, we conclude with some discussions and policy implications for public policies governing travel regulations for international couples.

\subsection{International mobility during the COVID-19 pandemic}

One dimension of the measures implemented during the COVID-19 is the drastic restriction of international mobility. Most countries have implemented travel bans and/or border enforcement 
measures in response to the pandemic (Martin \& Bergmann, 2021). However, the degree of intensity of these measures greatly varies from one country to another. Based on the data from the Oxford COVID-19 Government Response Tracker (Hale et al., 2021), figure 1 illustrates the intensity of border enforcement measures on four levels: (1) screening, (2) quarantine if from high-risk regions, (3) ban on travel from high-risk regions, and (4) total border closure. All countries for which data was collected have implemented some type of measures to regulate international travel. Among these, more than a dozen countries, including Algeria, Argentina, Australia, Denmark, and Japan, have totally closed their borders. Other countries such as China, India, the United States, and most Northern and Western Europe (except France) have implemented a selective travel ban on travellers coming from high-risk regions. Brazil, Russia, and most countries in Central and South Africa have implemented a screening process to control cross-border migrations through quarantines and PCR tests without implementing a travel ban. Figure 1 gives an overview of the different measures as for mid-June 2021 - a period with a slight downward tendency in the spread of the virus due to the vaccination rollout.

Figure 1. International border enforcement measures as of the $15^{\text {th }}$ of June 2021 (187 countries)

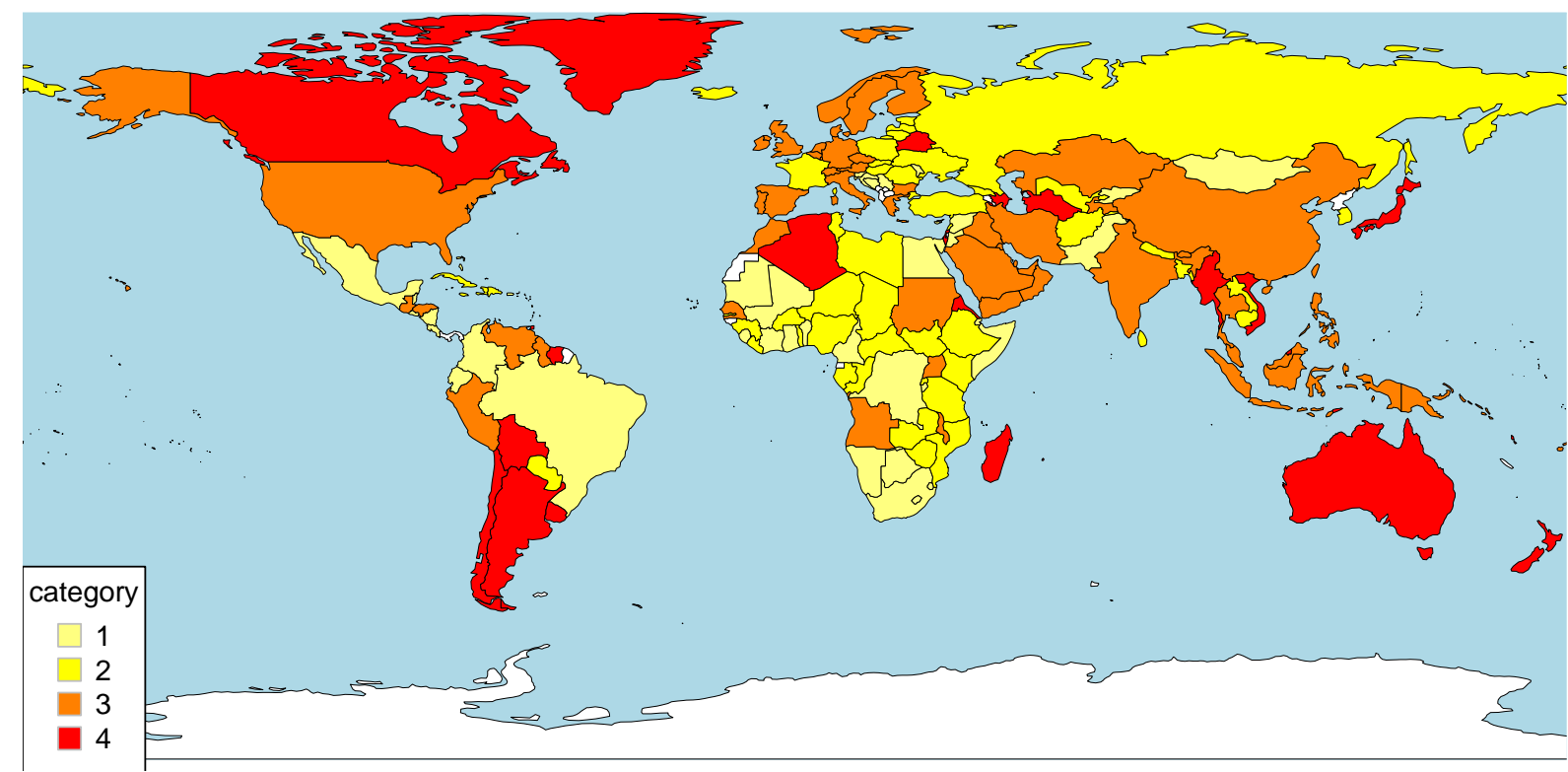

Source: data come from the Oxford Covid-19 Government Response Tracker (OxCGRT),

https://www.bsg.ox.ac.uk/research/research-projects/covid-19-government-response-tracker. Note: (0) No measures;

(1) Screening; (2) Quarantine arrivals from high-risk regions; (3) Ban on arrivals from some regions; (4) Ban on all regions or total border closure. Data for the $15^{\text {th }}$ of June 2021 except the following: Belarus $(24 / 05 / 2021)$; Jordan (01/06/2021) ; Egypt, Kenya (06/06/2021); Algeria, Bolivia, Djibouti, Senegal, Venezuela (07/06/2021); Suriname (12/06/2021); Botswana, Chile, United States (13/06/2021); Lesotho, Mauritania, Monaco, Seychelles, Sri Lanka, Sudan (14/06/2021). Missing data are in white.

The Oxford COVID-19 Government Response Tracker shows that the differences in infection rates alone do not fully explain the diversity of border control measures. For instance, the infection rates in neighbouring countries such as Canada and the United States, France and Belgium, Morocco and Algeria, or Japan and South Korea were not significantly different, but the border enforcement measures differed considerably. This suggests that the travel regulations in response 
to the pandemic were not driven solely or even primarily on epidemiological grounds. In fact, research suggests that the effectiveness of border enforcement measures in containing the epidemic is unclear, except, in the best case, a slowdown in the spread of the virus (Martin \& Bergmann, 2021; Wells et al., 2020). Often, it is more public opinions and the structures of countries' border policies that frequently drive different countries' responses to the pandemic (Kenwick \& Simmons, 2020). For instance, border control policies during the pandemic hence tend to be related to general views and sentiments on immigration which informed a given society prior to the pandemic (Lindholt et al., 2021). In this context, countries have been managing risk (Haug et al., 2020), often by externalizing the risk of the virus through limiting international travel instead of restricting domestic migration (Dantsuji et al., 2020). But it is difficult to draw a comparative global picture of border control measures, as there are variations by timing (most countries implemented a full travel ban at the start of the pandemic before relaxing their policies (Bou-Karroum et al., 2021)) as well as by the country and/or nationality of origin (Sabat et al., 2020).

In particular, the Oxford Tracker gives an overall picture of the variations in different governments' responses to COVID-19, but it does not inform of the specific cross-country variations regarding to whom the travel restrictions and exemptions apply among the countries with partial or complete border closure. For instance, while Australia and Japan both have closed their borders, Australia has closed its borders for everyone, independently of nationality or citizenship, whilst Japan has distinguished between Japanese nationals who can enter the country and long-term and short-term foreign residents who cannot at the early stage of the pandemic (Wels, 2021a, 2021b). Likewise, for countries that ban travel from or to some or all regions, there exist differences as to whether exemptions exist for those in married or other legally recognised relationships, as well as those who are in romantic relationships that are not formalised and legally recognised, which the Oxford Tracker does not investigate. As a result, there is little systematic knowledge about cross-country variations in how travel regulations and exemptions apply to those who seek to reunite with their partners in formal or informal relationships.

\subsection{International mobility of international couples}

The international immobility that binational couples experience during the COVID-19 pandemic is the result of three overlapping dimensions. First, it is an extension of the family and marriage migration restrictions that existed decades before the pandemic. Second, it is a result of the mixture of public policies implemented based on epidemiological as well as non-epidemiological grounds. Finally, it is a consequence of the informal routes for international mobility, namely tourist visas or visa waiver for tourism purposes, which have been used by international informal couples in the pre-pandemic times to reunite without necessarily having to formalise their relationship. In other words, the pandemic mobility context is a mixture of path dependencies and rapid policy changes that underlines what might not be seen in pre-pandemic time.

More generally, intimate international unions are not a new phenomenon. They have certainly intensified during colonial times (Fresnoza-Flot \& Wang, 2021) and the growth in both legal or undocumented international migrations over the second half of the twentieth century (Holzmann \& 
Wels, 2020) has contributed to the increased rate of international formal and informal couples (Eurostat, 2012). Family reunion has been the dominant mode of legal entry into European member states over the past 30 years after the 'official' stop to labour migration (Kofman, 2004). However, family migration policies have grown increasingly restrictive in the past twenty years in many European countries (Block, 2015). Nowadays, European migration prioritises (preferably intraEuropean) migration for high-skilled or essential labour supply over that associated with marriage and family formation (Brettell, 2017), often depicted as a burden for the social welfare of the receiving countries or a cause for 'ethnic separatism' (Bonjour \& Block, 2016). Scheel \& Gutekunst (2019) emphasise that migratory marriage containment is driven by a hierarchy of (gender, race, and class) desirability concerning who can integrate the nation. The definition of who constitutes the family and which relations deserve rights is still highly determined by the state. In fact, while Europe offers a framework for cross-European mobility (Castro-Martín \& Cortina, 2015; Wray et al., 2014), binational marriages with non-European partners (Haandrikman, 2014) are - differently at national level - highly politicised (D'Aoust, 2013) and often suspected as circumventing immigration control to access residence rights and citizenship (Girona et al., 2017).

The control over international marriages or partnerships has become more critical during the pandemic when governments have found themselves having to choose which mobility is considered essential and which is not (Salazar, 2021). Some governments have had to deal with citizens' demands in long-distance but informal romantic relationships with non-nationals. The claims of the grassroots movements put pressure on governments to rethink migration rules which have been in place, though this political and legal awareness is certainly not uniform across the global landscape. Recent studies have addressed the effects of health risk containment measures on families and households within the country's borders or under an intra-country comparative perspective (Lebow, 2020; Prime et al., 2020). However, these studies tend to focus on the socalled sedentary families; very little is known about transnational families and relationships, and even less about non-formalized relations that are not formally recognised by the state.

\section{Data and methods}

The core purpose of the study is to address and compare the different levels of regulations that were implemented during the COVID-19 pandemic to allow couples in formal and informal relationships to reunite. To better frame these regulations, data were collected by a team of five researchers ${ }^{1}$ during June of 2021 for all countries of the world (except a few countries for which no information was available - see Appendix 1). This means that the results displayed in the present study are based on the restrictions and travel requirements that were in place during this timeframe. The data collection was based on information gathered from official institutions' web pages, namely, National Ministries of Health, Foreign Affairs, Tourism, and embassies and consulates, among others. If no information was available from the country, other online resources

\footnotetext{
${ }^{1}$ The team includes the authors and Mr Quentin Palama who helped in the data collection process.
} 
such as news articles or blogs were referenced. The information gathered was also cross-checked with other online information from the \#LoveIsNotTourism web pages.

Data were collected over a four-step process, separately for legal and non-legal couples (see appendices 2 and 3 for the complete list of the questions answered in the data collection process). Firstly, we have assessed whether the country implemented border controls through flight cancellation and/or travel regulations towards travellers from most foreign countries. In this case, the focus was not on whether the country of interest implemented travel limitations for some specific migration corridors (for a discussion of migration corridors, see: Holzmann et al., 2016) but whether it concerned most foreign countries, independently from the health checks that were implemented for the travellers entering the national territory, such as quarantines or PCR tests. Secondly, in the case the country of interest did not implement visa restrictions, it was assessed whether tourist visas or visa waivers for tourism were still in place. Thirdly, in case border enforcement measures were implemented, we looked at whether there were some specific exemptions for formal couples, on the one hand, and for informal ones, on the other hand. Fourthly, if exemptions were implemented, we looked at whether these regulations imposed a defined timespan for reunion, whether there was a purpose for the reunion (e.g., marriage) and the requested proof of the relationship.

Two main indicators of cross-border mobility for formal and informal couples were created based on the different kinds of regulations identified. First, for our main analysis, we created a Couple Reunion Typology (CRT) based on four categories: (1) no travel ban, (2) travel ban with exemptions for couples in both types of relationships, (3) travel ban with exemption for couples in a formal relationship only, (4) full travel bans with no exemptions. Second, we conducted additional analysis based on a weight that sums up the different information about border enforcement, travel restrictions, timespan, the purpose of the reunion, and whether the reunion distinguished residents from non-residents. The weight is the sum of five sub-typologies (see appendix 4) that include different levels of information about the types of exemptions, the timespan of reunion, and whether it applied to all or a limited number of countries (country ban). The country weight $\left(\mathrm{W}_{\mathrm{n}}\right)$ is calculated as the sum of the four categories defined in the five sub-typologies. It is normalized as the ratio between the sum of the modalities and the sum of the modalities observed for each country $(\mathrm{N})$ and then, multiplied by the total number of countries (172 - information was missing for three countries).:

$$
W_{n}=\left[\frac{T_{1}+T_{2}+T_{3}+T_{4}+T_{5}}{\sum_{n}^{N}\left(T_{1}+T_{2}+T_{3}+T_{4}+T_{5}\right)}\right] * N
$$

The result section focuses on both the typology and the weights, examining the diversity of observed configurations, comparing our main typology with the Oxford Tracker typology, and finally, providing some estimates about the composition of the typology by region and country income group. We first focus on the results from the analysis based on our main Couple Reunion Typology, and at the end of the section we report findings from the additional analysis based on the typology which includes the weights. 


\section{Results}

\subsection{Patterns of regulations for the reunion of international couples}

Table 1 presents the number and proportion of countries for each category.

Table 1: Distribution based on the Couple Reunion Typology (CRT)

\begin{tabular}{llcc}
\hline Category & Indicators & N & $\%$ \\
\hline 1 & No travel restriction & 81 & 46.3 \\
2 & Border enforcement and special measures to allow formal and informal couples & 27 & 15.4 \\
3 & Border enforcement and special measures for formal couples & 26 & 14.9 \\
4 & Full travel ban for most foreigners & 41 & 23.4 \\
\hline
\end{tabular}

Figure 2 displays a visual representation of the diversity of travel restrictions for reunion worldwide (missing countries are in white).

Figure 2. Border enforcements for formal and informal couples by country in June 2021.

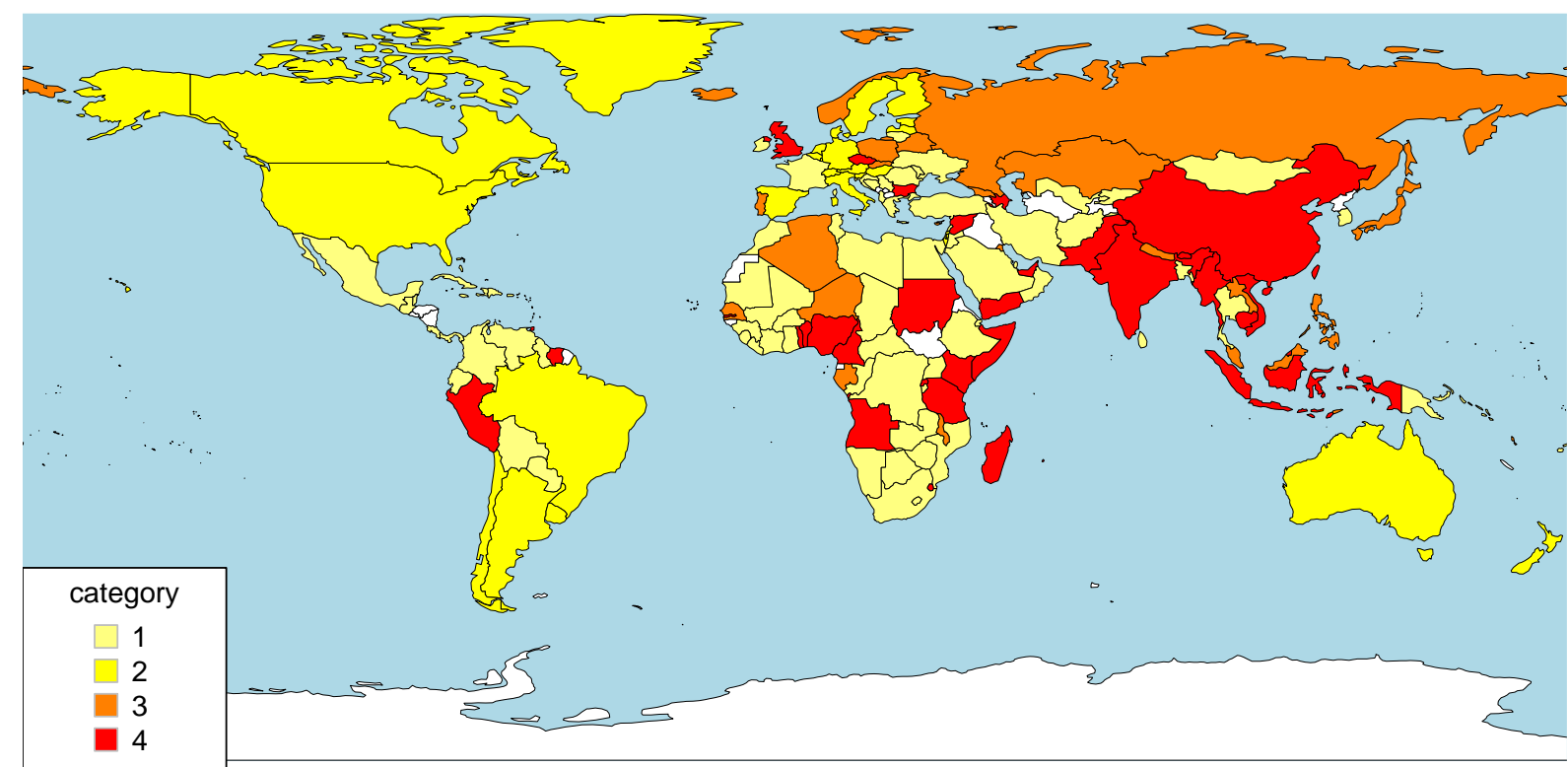

Note: $1=$ no travel restriction; $2=$ exemptions for formal and informal couples; $3=$ exemptions for formal couples only; $4=$ no exemptions.

The map in figure 2 demonstrates that there are some apparent regional patterns corresponding to the categories identified. East Asian countries are mainly in red (category 4), meaning that migration was made difficult for both couples in formal and informal relationships, while most central and south African countries have adopted lighter border enforcement measures. To better understand this, the following section systematically compares the results from this map with the results shown in the previous map (the Oxford Tracker) and aggregates the results by region, subregion, and income group. 


\subsection{Comparison with the Oxford tracker}

The Oxford COVID-19 Government Response Tracker and the typology used in this study measure two different phenomena and cannot be compared on a numerical basis; both typologies distinguish categories that do not have a numerical order, even though they are coded from lighter to stricter border enforcement measures. To better understand the relation between the two typologies, we use a Chi-Square method calculated through a contingency table (Table 2).

Table 2. Contingency table comparing the Oxford COVID-19 Government Response tracker with the CRT typology.

\begin{tabular}{|c|c|c|c|c|c|c|c|}
\hline \multirow{2}{*}{ Typology } & & \multicolumn{5}{|c|}{ Oxford Tracker } & \multirow{2}{*}{ Total } \\
\hline & & NA & 1 & 2 & 3 & 4 & \\
\hline \multirow{4}{*}{1} & observed values & 3 & 30 & 32 & 16 & 1 & 82 \\
\hline & expected values & 2 & 19 & 25 & 25 & 11 & 82 \\
\hline & $\%$ within Typology & $3.7 \%$ & $36.6 \%$ & $39 \%$ & $19.5 \%$ & $1.2 \%$ & $100 \%$ \\
\hline & $\%$ within Oxford Tracker & $75 \%$ & $73.2 \%$ & $59.3 \%$ & $29.6 \%$ & $4.3 \%$ & $46.6 \%$ \\
\hline \multirow{4}{*}{2} & observed values & 1 & 2 & 3 & 13 & 8 & 27 \\
\hline & expected values & 1 & 6 & 8 & 8 & 4 & 27 \\
\hline & $\%$ within Typology & $3.7 \%$ & $7.4 \%$ & $11.1 \%$ & $48.1 \%$ & $29.6 \%$ & $100 \%$ \\
\hline & $\%$ within Oxford Tracker & $25 \%$ & $4.9 \%$ & $5.6 \%$ & $24.1 \%$ & $34.8 \%$ & $15.3 \%$ \\
\hline \multirow{4}{*}{3} & observed values & 0 & 2 & 9 & 10 & 5 & 26 \\
\hline & expected values & 1 & 6 & 8 & 8 & 3 & 26 \\
\hline & $\%$ within Typology & $0 \%$ & $7.7 \%$ & $34.6 \%$ & $38.5 \%$ & $19.2 \%$ & $100 \%$ \\
\hline & $\%$ within Oxford Tracker & $0 \%$ & $4.9 \%$ & $16.7 \%$ & $18.5 \%$ & $21.7 \%$ & $14.8 \%$ \\
\hline \multirow{4}{*}{4} & observed values & 0 & 7 & 10 & 15 & 9 & 41 \\
\hline & expected values & 1 & 10 & 13 & 13 & 5 & 41 \\
\hline & $\%$ within Typology & $0 \%$ & $17.1 \%$ & $24.4 \%$ & $36.6 \%$ & $22 \%$ & $100 \%$ \\
\hline & $\%$ within Oxford Tracker & $0 \%$ & $17.1 \%$ & $18.5 \%$ & $27.8 \%$ & $39.1 \%$ & $23.3 \%$ \\
\hline \multirow{4}{*}{ Total } & observed values & 4 & 41 & 54 & 54 & 23 & 176 \\
\hline & expected values & 4 & 41 & 54 & 54 & 23 & 176 \\
\hline & $\%$ within Typology & $2.3 \%$ & $23.3 \%$ & $30.7 \%$ & $30.7 \%$ & $13.1 \%$ & $100 \%$ \\
\hline & $\%$ within Oxford Tracker & $100 \%$ & $100 \%$ & $100 \%$ & $100 \%$ & $100 \%$ & $100 \%$ \\
\hline
\end{tabular}

Results from Table 2 suggest - based on the Pearson's Chi-squared test and its corresponding pvalue - that there is a significant association between the Oxford tracker and our typologies. However, it also indicates that the relationship between the typologies is only partial. In other words, although the Oxford Tracker typology and our typologies are significantly associated, each of them is measuring a different pattern.

\subsection{Regional patterns}

Figure 2 suggests that there are heterogeneities across countries with some minor regional trends. However, the figure by itself is not enough to arrive at accurate conclusions. Tables 3 to 5 display the descriptive statistics using the ILO region and World Bank Income Group classifications, respectively. Table 3 shows that fully open borders are the norm in Africa, the Americas, and some Arab states, with 56.3, 65.6, and 54.5 percent of the countries have kept their borders open to most migrants, respectively. In contrast, a full closure is the norm in the Asia-Pacific region, but around a third of the countries kept their borders open. Finally, most European and Central Asian countries have not fully closed their borders, but countries vary 
widely in whether their borders were fully or partially open. Most countries have not closed their borders to formal couples, and more than two-thirds of countries were either fully open or provided exemptions for both formal and informal couples.

Table 3. Main typology repartition by ILO region

\begin{tabular}{|c|c|c|c|c|c|c|}
\hline \multirow[b]{2}{*}{ Categories } & \multicolumn{6}{|c|}{ ILO Region - percent $(N)$} \\
\hline & Africa & Americas & Arab States & $\begin{array}{c}\text { Asia and the } \\
\text { Pacific }\end{array}$ & $\begin{array}{c}\text { Europe and } \\
\text { Central Asia }\end{array}$ & $\begin{array}{l}\text { total } \\
(\mathrm{N})\end{array}$ \\
\hline 1 & $56.3(27)$ & $65.6(21)$ & $54.5(6)$ & $28.6(10)$ & $34.7(17)$ & 81 \\
\hline 2 & $0(0)$ & $21.9(7)$ & $9.1(1)$ & $8.6(3)$ & $32.7(16)$ & 27 \\
\hline 3 & $10.4(5)$ & $0(0)$ & 9.1. (1) & $25.7(9)$ & $22.4(11)$ & 26 \\
\hline 4 & $33.3(16)$ & $12.5(4)$ & $27.3(3)$ & $37.1(13)$ & $10.2(5)$ & 41 \\
\hline Total $(\mathrm{N})$ & 48 & 32 & 11 & 35 & 49 & 175 \\
\hline
\end{tabular}

Note: ILO region categories retrieved from the ILO website. Authors' calculation.

Beyond these regional variations, sub-regional variations play a key role, particularly in Asia and the Pacific and Europe and Central Asia. To better understand this, we present Table 4, which shows the repartition of each type by ILO subregion. For Type 2 (exemptions for formal and informal couples), there is a clear pattern: zero percent of the countries have implemented exemptions for informal couples in the Caribbean, Central Africa, Central America, Central Asia, Eastern Africa, Eastern Asia, Northern Africa, Southern Africa, and Southern Asia. One of the reasons is that these subregions have introduced polarized measures, keeping the border either fully open or fully closed to international travellers. By contrast, exemptions for informal couples were implemented in nearly half of Northern European countries, in a third of South American countries, and a quarter of South European countries.

Table 4. Main typology repartition by ILO subregion

ILO Subregion - percent $(N)$

\begin{tabular}{|c|c|c|c|c|c|c|c|c|c|c|}
\hline Categories & $\begin{array}{c}\text { Arab } \\
\text { States }\end{array}$ & Caribbean & $\begin{array}{c}\text { Central } \\
\text { Africa }\end{array}$ & $\begin{array}{c}\text { Central } \\
\text { America }\end{array}$ & $\begin{array}{c}\text { Central } \\
\text { Asia }\end{array}$ & $\begin{array}{c}\text { Eastern } \\
\text { Africa }\end{array}$ & $\begin{array}{c}\text { Eastern } \\
\text { Asia }\end{array}$ & $\begin{array}{l}\text { Eastern } \\
\text { Europe }\end{array}$ & $\begin{array}{c}\text { Northern } \\
\text { Africa }\end{array}$ & $\begin{array}{l}\text { Northern } \\
\text { America }\end{array}$ \\
\hline 1 & $54.5(6)$ & $81.8(9)$ & $57.1(4)$ & $100(5)$ & $66.7(2)$ & $46.7(7)$ & $28.6(2)$ & $30(3)$ & $66.7(4)$ & $25(1)$ \\
\hline 2 & $9.1(1)$ & $0(0)$ & $0(0)$ & $0(0)$ & $0(0)$ & $0(0)$ & $0(0)$ & $10(1)$ & $0(0)$ & $75(3)$ \\
\hline 3 & $9.1(1)$ & $0(0)$ & $14.3(1)$ & $0(0)$ & $33.3(1)$ & $6.7(1)$ & $28.6(2)$ & $40(4)$ & $16.7(1)$ & $0(0)$ \\
\hline 4 & $27.3(3)$ & $18.2(2)$ & $28.6(2)$ & $0(0)$ & $0(0)$ & $46.7(7)$ & $42.9(3)$ & $20(2)$ & $16.7(1)$ & $0(0)$ \\
\hline Total & 11 & 11 & 7 & 5 & 3 & 15 & 7 & 10 & 6 & 4 \\
\hline Categories & $\begin{array}{l}\text { Northern } \\
\text { Europe }\end{array}$ & $\begin{array}{l}\text { Pacific } \\
\text { Islands }\end{array}$ & $\begin{array}{c}\text { South } \\
\text { America }\end{array}$ & $\begin{array}{c}\text { South- } \\
\text { Eastern } \\
\text { Asia }\end{array}$ & $\begin{array}{l}\text { Southern } \\
\text { Africa }\end{array}$ & $\begin{array}{c}\text { Southern } \\
\text { Asia }\end{array}$ & $\begin{array}{l}\text { Southern } \\
\text { Europe }\end{array}$ & $\begin{array}{c}\text { Western } \\
\text { Africa }\end{array}$ & $\begin{array}{c}\text { Western } \\
\text { Asia }\end{array}$ & $\begin{array}{l}\text { Western } \\
\text { Europe }\end{array}$ \\
\hline 1 & $18.2(2)$ & $33.3(3)$ & $50(6)$ & $9.1(1)$ & $66.7(4)$ & $50(4)$ & $58.3(7)$ & $57.1(8)$ & $20(1)$ & $25(2)$ \\
\hline 2 & $45.5(5)$ & $22.2(2)$ & $33.3(4)$ & $9.1(1)$ & $0(0)$ & $0(0)$ & $25(3)$ & $0(0)$ & $20(1)$ & $75(6)$ \\
\hline 3 & $18.2(2)$ & $22.2(2)$ & $0(0)$ & $36.4(4)$ & $0(0)$ & $12.5(1)$ & $16.7(2)$ & $14.3(2)$ & $40(2)$ & $0(0)$ \\
\hline 4 & $18.2(2)$ & $22.2(2)$ & $16.7(2)$ & $45.5(5)$ & $33.3(2)$ & $37.5(3)$ & $0(0)$ & $28.6(4)$ & $20(1)$ & $0(0)$ \\
\hline Total & 11 & 9 & 12 & 11 & 6 & 8 & 12 & 14 & 5 & 8 \\
\hline
\end{tabular}

Note: ILO subregion categories retrieved from the ILO website. Authors' calculation.

Finally, these regional and subregional patterns reflect differences in border enforcement for formal and informal couples by income groups (Table 5). Among the type 2 countries - i.e., those who have implemented exemptions for both formal and informal couples -, most $(\mathrm{N}=24)$ are high- 
income countries against two that are upper-middle income countries (Argentina and Brazil) and only one that is a lower-middle income country (Palestine). In low-income countries, we observe a certain kind of polarisation between the countries that remained fully open ( 58.3 percent) and those that were fully closed (33.3 percent). No low-income country has implemented border enforcement measures with travel exemption for informal couples, and 8.3 percent had exemptions for formal couples.

Table 5. Main typology repartition by World Bank Income Group

\begin{tabular}{|c|c|c|c|c|c|}
\hline \multirow[b]{2}{*}{ Categories } & \multicolumn{5}{|c|}{ World Bank Income Group - percent (N) } \\
\hline & $\begin{array}{c}\text { High } \\
\text { income }\end{array}$ & $\begin{array}{l}\text { Upper-middle } \\
\text { income }\end{array}$ & $\begin{array}{c}\text { Lower-middle } \\
\text { income }\end{array}$ & $\begin{array}{c}\text { Low } \\
\text { income }\end{array}$ & $\begin{array}{c}\text { Total } \\
(\mathrm{N})\end{array}$ \\
\hline 1 & $30.3(20)$ & $61.9(26)$ & $48.8(21)$ & $58.3(14)$ & 81 \\
\hline 2 & $36.4(24)$ & $4.8(2)$ & $2.3(1)$ & $0(0)$ & 27 \\
\hline 3 & $15.2(10)$ & $16.7(7)$ & $16.3(7)$ & $8.3(2)$ & 26 \\
\hline 4 & $18.2(12)$ & $16.7(7)$ & $32.6(14)$ & $33.3(8)$ & 41 \\
\hline Total $(\mathrm{N})$ & 66 & 42 & 43 & 24 & 175 \\
\hline
\end{tabular}

\subsection{Further heterogeneities}

There is a diversity of conditions and requirements among the countries that have implemented exemptions for formal and informal couples. Among these conditions is the duration of the partners' stay in the host country, whether the regulations are based on the foreign partners' country of origin or nationality, and the purpose of the reunion. As mentioned in the methods section, a standardised weight was created to capture such further diversities across countries. Figure 3 illustrates these heterogeneities across Type 2 (exemptions for formal and informal couples) and Type 3 (exemptions for informal couples only) countries. Taking the European region as an example, we can observe heterogeneities even among Type 2 countries, for instance, with regulations relatively loose in Slovenia or Spain while stricter border requirements are in place in the Netherlands, Belgium, Austria, and even more so, in Luxembourg.

In short, travel regulations and degree of exemptions for couples in formal and informal relationships vary considerably across countries, even within the same region or subregion. The following section discusses in more detail some case studies thematically comparing several key aspects of heterogeneities. 
Figure 3. Weight of border enforcement measures for formal and informal couples for categories 2 and 3

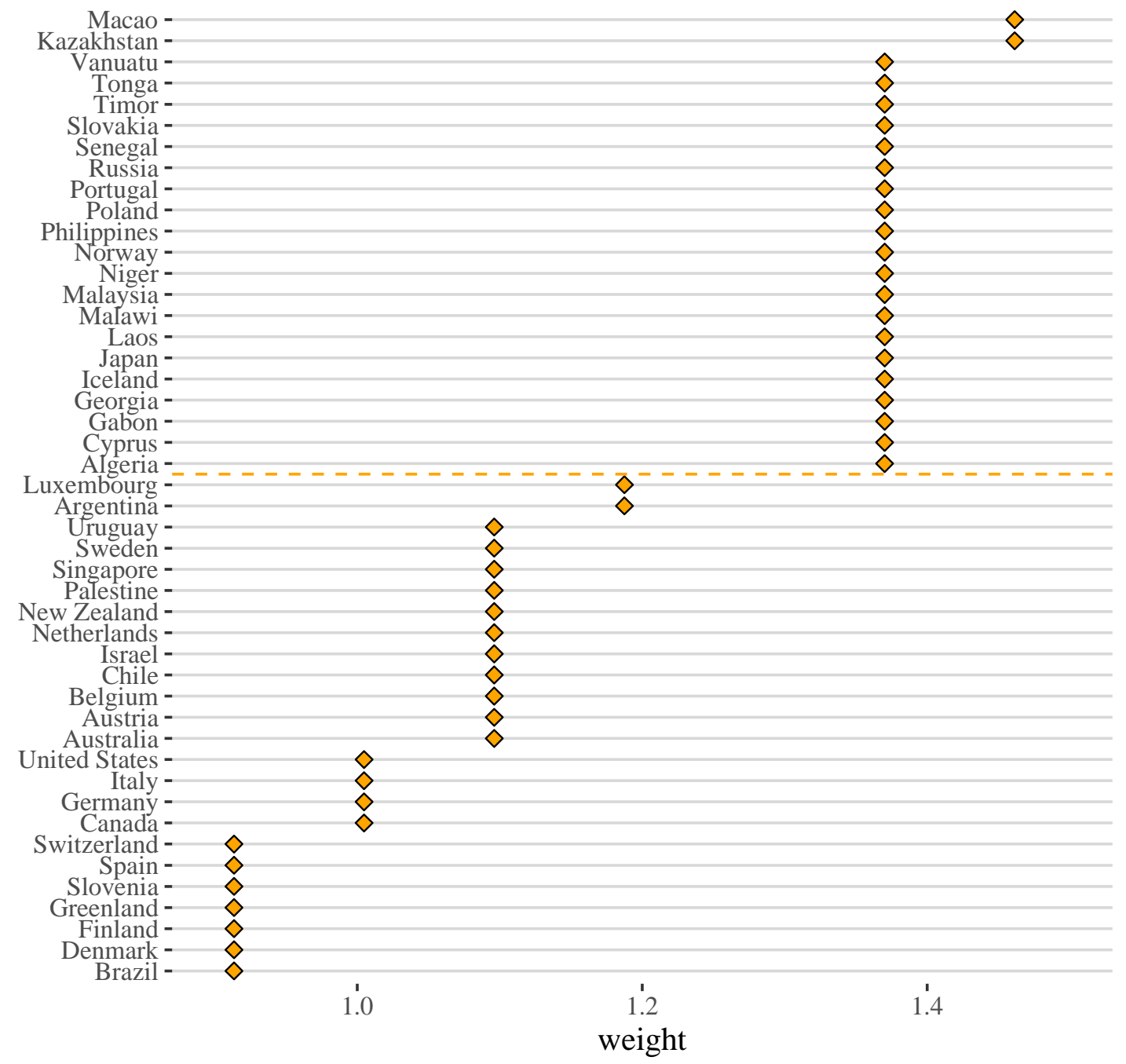

\subsection{Thematic case studies of regulations and exemptions}

\subsubsection{Marriage normativity: Privileging couples in formal relationships}

A normative logic favouring marriage and other formal unions underlies the position of countries that have introduced exemptions allowing international couples in formal relationships to travel but not those in informal relationships. Here we discuss in more detail two countries - Chile and Singapore - to demonstrate the background in which travel regulations and exemptions are implemented.

Family normativity continues to perpetuate inconsistencies between what is regulated by policies and the reality experienced by couples in the South American region, leading to travel regulations that do not represent the lives of its population. For instance, in Chile, more than 70 percent of children are born out of a formalized union, and at least 40 percent of those children are born in consensual unions (Wiegand, 2018), figures that more or less describe the situation in most other 
Latin American countries as well. Consensual but informal unions have increasingly become the preferred form of the first union, meaning couples tend to have a period of cohabitation after which they transition to marriage or civil partnership. Moreover, a significant number of couples never formalise their union. This means that couples in Chile as well as many other Latin American countries are more likely to be in an informal cohabitation than in other forms of relationships. Nonetheless, from March 2021 until the end of July 2021, when the Chilean government decided to close the air, maritime, and land borders for the transit of non-resident foreigners, it introduced exceptions only for foreign parents or children of a Chilean or foreigner regularly residing in the national territory and foreigners who are married or have a civil union with a Chilean or foreigner regularly residing in the national territory. As a result, foreigners in informal unions or commonlaw relationships were not able to enter the country. This demonstrates how travel regulations previliged couples in married relationships despite it not being the most common form of relationship in the region.In the case of Singapore, it has halted the entry of foreign travellers coming from most parts of the world (i.e., all countries/regions, except Australia, Brunei, Hong Kong, Macao, Mainland China, and New Zealand) but does have an exemption clause allowing family members to reunite. For a foreign partner to be eligible for travel into Singapore, one must be either an immediate family member or, interestingly, a fiancé/fiancée of a Singaporean Citizen or Permanent Resident (ICA, 2021). The notable feature of Singapore's exemption allowing couples to reunite is that it explicitly outlines and privileges (prospective) marriage as a condition, meaning those who have no intention to get married cannot reunite with their partners, no matter how long they have been together as a couple. While it is common for Asian countries not to recognise relationships unless legally recognised as a basis of travel exemptions, Singapore is exceptional in that it includes prospective spouses in the exemption category. The preferential treatment toward those expected to enter a marriage relationship can be understood in line with the Singaporean state's broader position regarding marital status. The Singaporean state is well-known for its 'social engineering' of citizens' family formation (Teo, 2010). The state offers couples a range of incentives and benefits to get married and have children, including financial bonuses, tax incentives, and housing subsidies. Cohabitation is not an accepted cultural norm, and neither are childless marriages (Strijbosch, 2015). In this context, the government actively nudges people into marriage and parenthood. The differential treatment of those with concrete plans to be married to reunite with their partners during the pandemic can be seen as an extension of these conjugal privileges.

The cases of Chile and Singapore illustrate how the states' normative approach to and preferenfial treatment of married (or soon-to-be-married) couples inform the travel regulations in place in countries which have introduced exemptions for couples in formal relationships but not those in informal relationships. Couples not in formalised relationships (who also do not have immediate plans to enter marriage) are unable to access the same rights to reunite with their partner that those in marriage relationships can, regardless of the de facto nature of their relationship.

\subsubsection{What counts as a relationship? Different standards and requirements}


While some countries - mostly European - appear to be better at accommodating the needs of formal and informal couples than the rest of the world, there are significant variations in the standards and proof of relationship that these countries require. For instance, the minimum duration of relationship that countries require couples to have been in ranges from two years (Finland) to three months (Denmark), with Canada's and Australia's one year and the Netherlands' six months in between. While some countries do not state a minimum period, Switzerland, for instance, requires couples to prove that the relationship has lasted for some time, regularly been cultivated and that credible evidence of regular contact is submitted, including proof of at least one face-to-face meeting either in Switzerland or abroad, on top of confirmation of the existing partnership.

The documentation that different countries require for couples to prove their informal relationships also widely differs. Australia is among the countries that have one of the most detailed and complicated guidelines. It requires that couples submit sufficient evidence of a de facto relationship demonstrating a mutual and exclusive commitment to a genuine and continuing relationship. Couples need to explain their relationship's application details, including how, when, and where they first met, how the relationship developed, what they do together and apart, significant events in the relationship, and future plans. In addition, couples are invited to demonstrate how they share finances (through joint mortgage or lease documents, joint loan documents for major assets like homes, cars or major appliances, joint bank account statements, or household bills in both names), the household matters (by explaining how they share housework, household bills in both names, email or emails addressed to both, or documents proving living arrangements), social matters (via joint invitations, proof of mutual friends, proof of joint social activities together, or proof of travelling together), commitment to a long-term relationship (including proof of knowledge of each other's background, family situation or other personal details demonstrated at an interview, proof of combined your personal matters, the terms of wills, and proof of contact during time apart).

Denmark, the first EU country to implement a travel exemption for in-dating couples (or the socalled "sweethearts" visa) - has relatively simple standards, requiring couples to have been in a relationship for three months or longer and to have met in person (not necessarily in Denmark). Among the documents to prove the relationship and apply for an exception is a 'solemn declaration in which the person resident in Denmark declares under penalty of perjury to be in a relationship with the person who wants to enter Denmark and that the purpose of the entry is to visit the person resident in Denmark. This declaration may be used for more than one entrance to be handed at the border control point. In contrast, France requires a "laissez-passer," i.e., a special travel document for foreign-French partners to cross the border to reunite. Sufficient material evidence must be submitted (e.g., pictures, invoices, private exchanges as emails, SMS, etc.) to prove that the relationship began more than six months before the outbreak of the pandemic (that means before September 2019), that the couple has met in France at least once, and that the foreign partner intends to return to their country of origin after a specific timespan. 
The discrepancies in both the minimum length and proof of relationship between different governments allowing the international travel of couples in informal relationships illustrate the subjective and arbitrary nature of what counts as a relationship when defining visa policies even in countries that have been prompted to implement travel exemptions for informal international couples.

\subsubsection{Other factors influencing international couples' reunion}

Finally, other practical factors related to border enforcement measures implemented during the pandemic influenced international couples' reunion, independently from the specific policies exempting foreign partners from the travel ban. Among those include different measures between land and air borders. For instance, Ghana reopened its air borders on the $1^{\text {st }}$ of September 2021 (this study captured the situation in June 2021), but land and sea borders remain closed. The opposite situation is observed in Kenya and Jordan, where no travel ban or border enforcement were implemented but international flights were cancelled. This generates a practical obstacle for certain couples to reunite and other migrants seeking to enter the host country.

Another obstacle is the implementation of 'list' systems such as in France or in the UK, where different levels of regulations applied to countries from the so-called green, orange/amber, and red countries, from requiring just positive COVID-19 checks to quarantine in designed accommodation at the migrant's expense. Although specific regulations for couples in formal and informal relationships apply independently from the country-of-origin classification, the list systems generate additional burdens for the foreign partner, making the reunion impossible in some cases.

Finally, flight companies also play an role in implementing border control and interpreting states' regulations. That is the case in Senegal, for instance, where border enforcement measures have mainly been implemented reciprocally in response to travel bans implemented by other countries. However, these are implemented through a request to airlines not to carry foreign nationals if they are not residents of Senegal but not through specific visa measures. Married partners who obtained a so-called récépissé providing them access to Senegal prior being a resident (i.e., the equivalent of a spouse visa) have been banned by some airlines even though the récépissé was recognised as the equivalent of a residency permit by the government. The role of airlines companies in interpreting such regulations might therefore be an obstacle in couples' reunion.

\section{Discussions and conclusion}

The COVID-19 pandemic has generated massive disruptions to cross-border migration, but no systematic cross-national research has been examined differences in border enforcement measures for formal and informal couples. The main aim of this study was to address such a gap and provide a comparative global picture of the possibilities for formal and informal couples to reunite at a specific point of time (June 2021) during the pandemic. The key finding is that most countries have implemented border enforcement measures and temporarily stopped travel for tourist 
purposes, which was the most common means of reunion for international couples in informal relationships. Among these countries, a limited number have implemented specific regulations to allow couples in formal relationships to reunite, and an even smaller number of countries have implemented exemptions for couples in informal relationships, primarily high-income countries. Among countries that have implemented specific regulations for those categories of migrants, there is great variability in the evidence of a relationship that needs to be submitted, the definition of what counts as a relationship, and the purpose and timespan for reunion. Some further practical factors make it more difficult for couples to reunite, including flight cancellations and the 'list'systems.

This study is not without limitations, particularly in terms of data collection. First, data collected for this study describe the picture of cross-border migration for formal and informal couples at a specific point in time but do not account for the changing nature of border enforcement measures throughout the pandemic. Second, data reflect what was implemented in most receiving countries, but no data was collected on whether citizens from these countries were allowed to move (and come back) from their origin country. Third, data were collected worldwide and did not account for corridor and regional migration flows. In other words, the study has looked up at border enforcement measures applied to most countries, not at the rules implemented for a defined and limited number of countries by some (e.g., the Australia-New Zealand migration resuming agreement). Finally, the study did not distinguish between the mobility of couples in heterosexual unions and those in non-heterosexual unions (Hoffmann \& Velasco, 2021). However, one can certainly expect that international reunion would have been more challenging for couples in samesex relationships, especially if they seek to travel to (and from) a country that does not recognise or bans same-sex unions.

Nevertheless, the study addresses issues that have been overlooked by the academic community as well as policymakers. So far little attention has been paid to the cross-national mobility of couples in informal relationships, even during the pre-pandemic times. As the number of international migrants has continued to grow over the past decades, international informal relationships have also became more common but visa regulations have not introduced separate regulations for the travel of foreigners in such international relationships with their partners. Consequently, couples in international informal relationships have had to resort to tourist visas in order to reunite with their partners.

At the same time, the implementation of border enforcement measures during the pandemic has led most countries to drastically restrict international migration, including tourism. This has had an impact on couples in formal relationships and more so on those in informal relationships. In such a context and whilst border enforcement measures are still in place in most countries for the time being (October 2021), this study highlights the fact that countries have implemented very diverse regulations but that full border for closure for international couples can be avoided through specific regulations that allow both formal and informal couples to reunite, under specific conditions. The implementation of such regulations is possible, but its effectiveness depends on 
several factors. A first factor is about whether state recognize consensual forms of unions or not, independently from whether partners live in the same country. A second factor is about the types of border enforcement measures that have been implemented and the possibility or not to implement exemptions. It is obvious that exemptions cannot be implemented on the ground of flight cancellation policies but only on border enforcement measures that do not fully cancel the movement of people. A third factor is about introducing realistic and straightforward requirements for proofs of relationship that would meet the needs of couples seeking reunion as well as states' need to exercise reasonable control over international migration.

Finally, it must be mentioned that the ongoing and gradual relaxation of border enforcements measures has led many countries to move back to pre-pandemic regulations, which means that international couples need to go back to relying on travel as tourists to reunite with their partners. We believe that the issues raised during the COVID-19 crisis could be taken as an opportunity to fundamentally rethink the possibilities of developing a specific visa scheme for international formal and consensual unions. The crisis has clearly demonstrated that relying on tourist visas introduces uncertainties and difficulties for their reunion during times of crisis such as the pandemic. We hope this research may start a broader debate about the possibilities of more fundamental visa and travel reforms for the international mobility of couples in formal and consensual partnerships. 


\section{References}

Block, L. (2015). Regulating Membership: Explaining Restriction and Stratification of Family Migration in Europe. Journal of Family Issues, 36(11), 1433-1452. https://doi.org/10.1177/0192513X14557493

Bonjour, S., \& Block, L. (2016). Ethnicizing citizenship, questioning membership. Explaining the decreasing family migration rights of citizens in Europe. Citizenship Studies, 20(6-7), 779-794. https://doi.org/10.1080/13621025.2016.1191429

Bou-Karroum, L., Khabsa, J., Jabbour, M., Hilal, N., Haidar, Z., Abi Khalil, P., Khalek, R. A., Assaf, J., Honein-AbouHaidar, G., Samra, C. A., Hneiny, L., Al-Awlaqi, S., Hanefeld, J., El-Jardali, F., Akl, E. A., \& el Bcheraoui, C. (2021). Public health effects of travel-related policies on the COVID-19 pandemic: A mixed-methods systematic review. Journal of Infection. https://doi.org/10.1016/j.jinf.2021.07.017

Brettell, C. B. (2017). Marriage and migration. Annual Review of Anthropology, 46, 81-97. https://doi.org/10.1146/annurev-anthro-102116-041237

Castro-Martín, T., \& Cortina, C. (2015). Demographic Issues of Intra-European Migration: Destinations, Family and Settlement. European Journal of Population, 31(2), 109-125. https://doi.org/10.1007/s10680-015-9348-y

Dantsuji, T., Sugishita, K., \& Fukuda, D. (2020). Understanding changes in travel patterns during the COVID-19 outbreak in the three major metropolitan areas of Japan. ArXiv.

D'Aoust, A. M. (2013). In the Name of Love: Marriage Migration, Governmentality, and Technologies of Love. International Political Sociology, 7(3), 258-274. https://doi.org/10.1111/ips.12022

Eurostat. (2012). Merging populations. A look at marriages with foreign-born persons in European countries. Statistics in Focus, 29. https://ec.europa.eu/eurostat/documents/3433488/5584928/KS-SF12-029-EN.PDF/4c0917f8-9cfa-485b-a638-960c00d66da4

Fresnoza-Flot, A., \& Wang, S. (2021). Asia-Europe intimate links: Family migrants, binational couples and mixed-parentage children. Asian and Pacific Migration Journal, 30(1), 3-17. https://doi.org/10.1177/0117196820981596

Girona, J. R., Anzil, V., \& Yzusqui, R. (2017). Love and its borders: The monitoring and control of binational marriages in Spain. Anthropological Notebooks, 23(2), 21-37.

Haandrikman, K. (2014). Binational marriages in Sweden: Is there an EU effect? Population, Space and Place, 20(2), 177-199. https://doi.org/10.1002/psp.1770

Hale, T., Angrist, N., Goldszmidt, R., Kira, B., Petherick, A., Phillips, T., Webster, S., Cameron-Blake, E., Hallas, L., Majumdar, S., \& Tatlow, H. (2021). A global panel database of pandemic policies (Oxford COVID-19 Government Response Tracker). Nature Human Behaviour, 5(April). https://doi.org/10.1038/s41562-021-01079-8

Haug, N., Geyrhofer, L., Londei, A., Dervic, E., Desvars-Larrive, A., Loreto, V., Pinior, B., Thurner, S., \& Klimek, P. (2020). Ranking the effectiveness of worldwide COVID-19 government interventions. Nature Human Behaviour, 4(12), 1303-1312. https://doi.org/10.1038/s41562-020-01009-0

Hoffmann, N. I., \& Velasco, K. (2021). Making Migration Sexy: How LGB Policies Influence International Migration. SocArXiv, 15 Feb. 2021. https://doi.org/10.31235/osf.io/hxjkt

Holzmann, R., \& Wels, J. (2020). The cross-border portability of social security benefits: Status and progress? International Social Security Review, 73(1), 65-97. https://doi.org/10.1111/issr.12228

Holzmann, R., Wels, J., \& Dale, P. (2016). Assessing Benefit Portability for Migrant Workers: Lessons learned from a review of the France-Morocco bilateral social security agreement. The World Bank. 
Kenwick, M. R., \& Simmons, B. A. (2020). Pandemic Response as Border Politics. International Organization. https://doi.org/10.1017/S0020818320000363

Kofman, E. (2004). Family-related migration: A critial review of European studies. Journal of Ethnic and Migration Studies, 30(2), 243-262. https://doi.org/10.1080/1369183042000200687

Lebow, J. L. (2020). Family in the Age of COVID-19. In Family Process (Vol. 59, Issue 2, pp. 309-312). Blackwell Publishing Inc. https://doi.org/10.1111/famp.12543

Lindholt, M. F., Jørgensen, F., Bor, A., \& Petersen, M. B. (2021). Support for border security during the COVID-19 pandemic: evidence on levels and predictors from eight Western democracies in 2020. In Journal of Elections, Public Opinion and Parties (Vol. 31, Issue S1, pp. 1-14). Routledge. https://doi.org/10.1080/17457289.2021.1924743

Martin, S., \& Bergmann, J. (2021). (Im)mobility in the Age of COVID-19. International Migration Review, 55(3), 660-687. https://doi.org/10.1177/0197918320984104

Odasso, L. (2021a). Family rights-claiming as act of citizenship: an intersectional perspective on the performance of intimate citizenship. Identities, 28(1), 74-92. https://doi.org/10.1080/1070289X.2020.1723309

Odasso, L. (2021b). Negotiating Legitimacy: Binational Couples in the Face of Immigration Bureaucracy in Belgium and Italy. Anthropologica, 63(1). https://doi.org/10.18357/anthropologica6312021273

Odasso, L., \& Fogel, F. (2022). Immobilisation et mobilisation de la vie privée en temps de pandémie. Revue Européenne Des Migrations Internationales, To be published.

Prime, H., Wade, M., \& Browne, D. T. (2020). Risk and resilience in family well-being during the COVID-19 pandemic. American Psychologist, 75(5), 631-643. https://doi.org/10.1037/amp0000660

Sabat, I., Neuman-Böhme, S., Varghese, N. E., Barros, P. P., Brouwer, W., van Exel, J., Schreyögg, J., \& Stargardt, T. (2020). United but divided: Policy responses and people's perceptions in the EU during the COVID-19 outbreak. Health Policy, 124(9), 909-918. https://doi.org/10.1016/j.healthpol.2020.06.009

Salazar, N. B. (2021). Existential vs. essential mobilities: insights from before, during and after a crisis. Mobilities, 16(1), 20-34. https://doi.org/10.1080/17450101.2020.1866320

Scheel, S., \& Gutekunst, M. (2019). Studying marriage migration to Europe from below: informal practices of government, border struggles and multiple entanglements. Gender, Place and Culture, 26(6), 847-867. https://doi.org/10.1080/0966369X.2018.1489375

Strijbosch, K. (2015). Single and the City: State Influences on Intimate Relationships of Young, Single, Well-Educated Women in Singapore. Journal of Marriage and Family, 77(5), 1108-1125. https://doi.org/10.1111/jomf.12221

Teo, Y. (2010). Shaping the Singapore family, producing the state and society. Economy and Society, 39(3), 337-359. https://doi.org/10.1080/03085147.2010.486215

Wells, C. R., Sah, P., Moghadas, S. M., Pandey, A., Shoukat, A., Wang, Y., Wang, Z., Meyers, L. A., Singer, B. H., \& Galvani, A. P. (2020). Impact of international travel and border control measures on the global spread of the novel 2019 coronavirus outbreak. Proceedings of the National Academy of Sciences of the United States of America, 117(13), 7504-7509. https://doi.org/10.1073/pnas.2002616117

Wels, J. (2021a). Addressing the Impact of Border Enforcement Measures on the Self-Reported Health of Migrants Aiming to Enter Japan During the COVID-19 Epidemic. OSF Discussion Paper, osf.io/egq9p, 1-30. https://doi.org/10.31219/osf.io/egq9p 
Wels, J. (2021b). Assessing the Effects of Border Enforcement Measures Since the Start of the COVID19 Pandemic on Migrants Aiming to Enter Japan. Preliminary Descriptive Report (Version 1 - 4th of March 2021). METICES Discussion Paper Series, 4, 23.

Wray, H., Agoston, A., \& Hutton, J. (2014). A family resemblance? the regulation of marriage migration in Europe. European Journal of Migration and Law, 16(2), 209-247.

https://doi.org/10.1163/15718166-12342054 


\section{Appendix 1. Countries excluded from the study}

\begin{tabular}{|c|c|c|}
\hline & Country & Region \\
\hline 1 & Antigua and Barbuda & Caribbean \\
\hline 2 & Armenia & Southwest Asia \\
\hline 3 & Congo (Congo-Brazzaville) & West Africa \\
\hline 4 & El Salvador & Latin America \\
\hline 5 & Equatorial Guinea & Central Africa \\
\hline 6 & Grenada & Caribbean \\
\hline 7 & Guinea-Bissau & West Africa \\
\hline 8 & Honduras & Latin America \\
\hline 9 & Iraq & Southwest Asia \\
\hline 10 & Liechtenstein & Western Europa \\
\hline 11 & Maldives & South Asia \\
\hline 12 & Marshall Islands & Oceania \\
\hline 13 & Micronesia & Oceania \\
\hline 14 & Montenegro & East Europe \\
\hline 15 & Nauru & Oceania \\
\hline 16 & Nicaragua & Latin America \\
\hline 17 & North Korea & East Asia \\
\hline 18 & North Macedonia & East Europe \\
\hline 19 & Palau & Oceania \\
\hline 20 & Saint Kitts and Nevis & Caribbean \\
\hline 21 & Saint Lucia & Caribbean \\
\hline 22 & $\begin{array}{l}\text { Saint Vincent and the } \\
\text { Grenadines }\end{array}$ & Caribbean \\
\hline 23 & Samoa & Oceania \\
\hline 24 & Sao Tome and Principe & Central Africa \\
\hline 25 & Tuvalu & Oceania \\
\hline
\end{tabular}




\section{Appendix 2. Information gathered about travel regulations for formal couples}

\begin{tabular}{|c|c|}
\hline Question & Answer \\
\hline Have there been changes in travel regulation due to COVID? & No /Yes \\
\hline Is tourism from most countries prohibited? & No /Yes \\
\hline $\begin{array}{l}\text { Are there specific exemptions for couples in formalised } \\
\text { relationships? }\end{array}$ & No /Yes \\
\hline $\begin{array}{l}\text { If exemptions are in place, do they apply to nationals only or } \\
\text { nationals and residents? }\end{array}$ & $\begin{array}{l}\text { Nationals and Residents / } \\
\text { Nationals Only }\end{array}$ \\
\hline $\begin{array}{l}\text { If exemptions are in place, does the nationality /citizenship of the } \\
\text { partner/spouse matter? }\end{array}$ & No /Yes \\
\hline $\begin{array}{l}\text { If exemptions regulations are in place, do they apply to those } \\
\text { having children only? }\end{array}$ & No /Yes \\
\hline $\begin{array}{l}\text { If exemptions are in place, is the reunion allowed for a limited } \\
\text { span of time? }\end{array}$ & No /Yes \\
\hline $\begin{array}{l}\text { If exemptions are in place, do couples need to provide proof of } \\
\text { relationship? }\end{array}$ & No /Yes \\
\hline $\begin{array}{l}\text { If applicable, what kind of proof of the relationship do couples } \\
\text { need to submit? }\end{array}$ & Qualitative answers \\
\hline $\begin{array}{l}\text { If exemptions are in place, do they apply to all countries, or are } \\
\text { some countries are banned from entering? (Order should be } \\
\text { changed. Either push the question on nationals and residents down, } \\
\text { or push this one up.) }\end{array}$ & All countries / Not all countries \\
\hline
\end{tabular}




\section{Appendix 3: Information gathered about travel regulations for informal couples}

\begin{tabular}{|l|c|}
\hline Question & Answer \\
\hline Are there exemptions for couples in informal relationships? & No /Yes \\
\hline $\begin{array}{l}\text { If exemptions are in place, do they apply to nationals only or } \\
\text { nationals and residents? }\end{array}$ & $\begin{array}{c}\text { Nationals and Residents / } \\
\text { Nationals Only }\end{array}$ \\
\hline $\begin{array}{l}\text { If exemptions are in place, does the nationality/citizenship of the } \\
\text { partner matter? }\end{array}$ & No /Yes \\
\hline $\begin{array}{l}\text { If exemptions are in please, do they apply to those having children } \\
\text { only? }\end{array}$ & No /Yes \\
\hline $\begin{array}{l}\text { If exemptions are in place, is the reunion allowed for a limited } \\
\text { span of time? }\end{array}$ & No /Yes \\
\hline $\begin{array}{l}\text { If exemptions are in place, do couples need to provide proof of } \\
\text { relationship? }\end{array}$ & Qualitative answer \\
\hline $\begin{array}{l}\text { If applicable, what kind of proof of the relationship do couples } \\
\text { need to submit? }\end{array}$ & All countries / Not all \\
countries
\end{tabular}


Appendix 4: Sub-typologies by type of travel restrictions, used to estimate the weights
Sub-typology 1. Exemption by type of couple
(1) No travel restriction
(2) Exemptions for formal and informal couples
(3) Formal couples only
(4) No exemptions

Sub-typology 2. Time span for formal couples

(1) No travel restriction

(2) No defined timespan for formal couples

(3) Defined timespan for formal couples

(4) No exemptions

Sub-typology 5. Country ban for information couples

(1) No travel restriction

(2) Exemptions for information couples and no country ban

(3) Exemptions for informal couples and country ban

(4) No exemptions
Sub-typology 3. Country ban formal couples
(1) No travel restrictions
(2) Formal couples and no country ban
(3) Formal couples and country ban
(4) No exemptions

\section{Sub-typology 4. Time span for informal couples}

(1) No travel restriction

(2) No defined timespan for informal couples

(3) Defined timespan for informal couples

(4) No exemptions 